\title{
Communication in Banking Sector: A Systematic Review
}

\author{
Sulochana Shrestha ${ }^{{ }^{*}}$, Seeprata Parajuli ${ }^{\text {(D) }}$ and Udaya Raj Paudel ${ }^{1,2}$
}

1 Quest International College, Pokhara University, Nepal

2 PhD Scholar, Tribhuvan University, Kathmandu, Nepal

Corresponding Author (me.silurian@gmail.com)

Received:27 Sept, 2019

Revised: 25 Nov, 2019

Accepted: 15 Dec, 2019

Published: 28 Jan, 2020

How to cite this paper: Shrestha, S., Parajuli, S., Paudel, U. R. (2019). Communication in banking sector: A systematic review. Quest Journal of Management and Social Sciences, 1(2), 272-284.

Copyright (C) 2019 by authors and Quest Journal of Management and Social Sciences

This work is licensed under a Creative Commons Attribution-NonCommercial-NoDerivatives 4.0 International License.

https://creativecommons.org/licenses/ by-nc-nd/4.0/

\begin{abstract}
Background: Effective banking communication strengthens the relationship between customer, suppliers, stakeholders, manager, client, employees and board of directors. Banker's experience on banking communication enhances banking system, employee's behavior and core banking services facilities management. Banking communication improves organizational effectiveness through training, knowledge management, risk management, internal control system and data security management. In modern era, communication channel is transformed into electronic channel promoting e-banking which includes internet banking, mobile banking and e-payment system. Moreover, clerical work shifted into electronic form, which cut costs and satisfy customer.
\end{abstract}

Objectives: This paper explores how banker's experience effects on banking communication in commercial banks, which enhances their understanding level and determines effective communication in workplace.

Methods: Extensive desk reviews followed by related literature were carried out to gain better insight regarding the field of study.

Findings: With the passage of time, computers and technologies have changed the traditional method of communication system. Banks are now using windows, world processing system, excel, computer operating system, DOS, database management system, data planning and database design, data security, internet, intranet, extranet service and email system which increase working performance.

Conclusions: Bank managers need to understand importance of communication skills in order to increase effectiveness of internal communication between manager and employees.

Implications: Commercial banks of Nepal require to update in their communication practices and strategies in order to build proper channel which would help in communication between employees and management.

Keywords: employees' perception, banking system, employees' behavior, core banking services facilities management, structural equation modeling

Paper Type: Review Paper

JEL Classification: D83, G21, O14, G53 


\section{Introduction}

Human relationship is indispensable part of communication. The origin of communication beganwith the human interaction. Communication in the working area has been dramatically evolved. Face to face communication has been renovated through development of landline phones, computers, mobile phones, Internet and sooner into virtual reality (Akmajian et al., 2017). In 1961 Massachusetts Institute of Technology (MIT) developed Compatible Time Sharing System (CTSS) for the first time in the operating systems. The time sharing system arrange requirement of user and coordinate their schedule and project in order to communicate regularly for information and maintain high productivity (Aladwani, 2001). The personal computers were introduced in marketplace in 1975, then in 1991 Aug 6 World Wide Web went to live and officially internet connection begun. After that employees started to communicate through via email and online message boards. In this way, history of communication in workplace began. These technologies kept employees virtual activities in office (Van Eemeren \& Grootendorst, 2016).

Moreover, effective communication can strengthen the connection between customer, suppliers, stakeholders, managers, client, employees, board of directors, neighbors, community and nation. Business communication is a complete package of bi- directional and transformational process (Thussu, 2018). Effective communication fosters ideas and build common ground to develop complex interpersonal relationships. The communication pattern has changed in form of telephone, email and fax into instant messaging/chat, virtual words, social networking sites, wikis, twitter, blogs in the workplace which become very beneficial to transfer information from one place to another place and save data and information (Rahman\&Masoom, 2015). Thus, communication become the wealth of information which can be in the form of facial expressions, body language, verbal, text, messages, voice message, video call, video conferencing and so on (Abdul-Wahab \& Haroon, 2017). Furthermore, effective communication facilitates cooperation; increases managerial efficiency; promotes cooperation and industry peace, smooth and efficient running of organization, job satisfaction, public relation; increases productivity and reduce cost, democratic management and basis of decision making and planning (Austin \&Pinkleton, 2015).

Communication is the medium to conduct meeting, discuss with each other regarding issues based on the functions and activities. Communication strategies play significant roles in effective management of fundamental policy govern by central bank. The central bank has announced four issues related to the communication in the central bank. The first communication issue is economic conditions, which collect information related to the current conditions of the economy (Amato, 2002; Berenstein\& Campbell, 2002). The second communication issue is policy decision made by central bank to target current operating. The third communication issue is the description of the strategy guided by the central bank to carry out the communication policy to the general. The fourth type of communication debate is outlook of the future policy, which generally increases transparency, and effective stabilization of the communication policy (Amato et al. 2002; Amato et al., 2015). To achieve sustainable development goals is important (B.K. et al, 2019). Bank is one of the important sectors to achieve development goals. There is still a gap in banking communication practice 
in workplace. The workers would like to adopt traditional method of record keeping information and data rather than adoption of modern technology. Moreover, there is difference in culture, language, caste, norms and ethnic group create communication gap between employees ( Cujoe et al., 2015; Deshmukh, 2004).

Ishaq Bhatti et.al (2011) explained banking communication focus on the customer satisfaction mainly depends on the employee's behavior towards customer. Moreover, employees performance depend on training, technical support, empowerment, rewards, recruitment, performance reviews motivation and selection of employees. Additionally, the employee's perception changes the service quality in international level. There are five internal service orientation dimensions which promote effective banking communication namely employees' training, employees service performance, service, concept, development and positioning, organizational knowledge and customer service orientation (Bennett \&Kottasz, 2012).

Banking communication is a relationship between communication management and banking system (Rai et al., 2019). Proper banking management communications create customer satisfaction and bank loyalty. Financial institutions like banks are encouraged to promote banking communication management because it fosters economic development as it manages risks, monitors managers, evaluates project, mobilizes saving and facilitates transaction (Keyton et. al. 2013). Banking communication is the process of interchanging information, ideas, and knowledge within or outside banks. The organization consists of different types of employees come from different sections of the society. Moreover, they have different cultural backgrounds guided by norms, religion, language, and ethnicity. The effective communication enhances productivity and efficiency of the employees (Turner, Biehi, Golochinsky \& Black, 2010).

Effective communication successfully collaborates the interpersonal relationship with employees. Interpersonal communication depends on the willingness of the individual communication. Social bonds, attention awareness and commitment increase inter personal behaviors (Nardi, 2005). Banking communication channels are not getting replaced; it is modified and updated with present scenario. Technological advancement enhances individual communication practices and attitudes in workplaces. Communication technologies have strengthened the working environment in workplace. Technological development changed the strategies of bank strategies of banking services. They focus on both commercial and individual customers through qualitative service. Bank expands their service quality implementing marketing strategies to enhance revenues; customer retention and cross sell ratios. Likewise, quality service delivery increases customers' loyalty to bank. Now, banking communication becomes competitive advantage in banking industries. (Scornavacca\&Hoehle, 2007).

Form the evidence mentioned above, we conclude that banking communication shows relationship between communication management and banking system. Proper banking communication creates customer satisfaction and promotes economic development. Moreover, banking communication interchange information, ideas and knowledge inside and outside banks. Effective communication successfully collaborate the interpersonal relationship with employees and enhance their working efficiency (Thomas et al., 2009). Thus, the importance of banking communication is increase day by day in banking system. 
This paper aims to explore how banker's experience affect banking communication in commercial banks that enhances their understanding level and determines effective communication in workplace. Likewise, the remaining part of the paper is organized in four sections. The following section reviews the relevant literature, followed by materials and methods used, then discussion of key findings and finally conclusion of the study.

\section{Review of Literature}

\section{Communication and Employee Relation}

The globalization has parallel effects on the development of organizational management and increased competition. The modern technology has raised employees' performance by using advance communication technology. Both organization and human are social beings interlinked with each other (Austin \&Pinkleton, 2015). Effective communication improves job satisfaction that directly improves in productivity. Thus, organizational communication and worker performance integrate different units and functions of an organization; communicating performance standard and expectation regularly observe activities of employees and provide them feedback (Aral et al., 2013). Moreover, effective internal communication successfully manages the strategic management of organization in order to engage employees and achieve objectives. Communication identifies corporate strategy, which drives organization towards their goal and objective. The means of communication set common goal in the organization, which focuses on achieving desired objectives in organization (Ahmad, 2006; Alleyne et al., 2007).

Proper communication between employees increase trust in organizations, which leads to the success on business organization. The relationships with supervisors and coworkers exchange all the information, which is the best practice of communication. Generally, communication management maintains the connection between employees to employees and employees to organization. Thus, it increases performance of organization effectively and efficiently (Harie et al., 2002; Kurland \& Bailey, 2000). Furthermore, management hesitates to practice effective communication, which becomes problematic for the organization as it develops lack of data and weak action plans. Most of the managers are poor at communication is one of the defect of organizations. Their improper communication leads to the organizational losses (Power \& Rienstra, 1990). Their unfriendly behavior might create problem of motivation. As a result their working efficiency will be decreases. Thus, banking communication play vital role to help managers to investigate real issues and problem in organization. With the passage of time, communication become tools to coordinate internal control system and drive organization into successful path (Thomson \&Hecker, 2001; Saida et al, 2016).

The flow of communication creates organizational goal, values, objective which helps to prepare strategies in organization. There is positive relationship between communication and employees (Smythe, 1996; Thomas et al., 2009). Moreover, effective communication increases overall organizational functioning, foundation of sound management, greater coordination and effective interaction among workers. Now, the placement of e-banking communication in bank improves performance of workers and increases efficiency in work (Svensson, 2004). 


\section{Importance of Banking Communication in Banking Sector}

Communication is essential part of management. The success and failure of organization depends upon the effective communication. Communication is a two-way channel of transferring ideas, plans, commands, reports and suggestions which influence organization in order to make desired objectives (Altinoz, 2009; Broca\&Baesu, 2014). The quality decision-making is based on the quality communication. Without quality information, it is impossible to delegate instruction and orders. Moreover, effective communication in organization increases smoothness and efficiency of organizations. The exchange of idea and information through communication helps to bring unity of action in organization which quests for the common objectives (Chen, 2008; Femi, 2014). Communication transfers goals and desires, training allocate duties, issues instructions and duty and responsibility and evaluated performance of staff. Thus, effective and efficient communication increases managerial efficiency (Arnold \& Silva, 2014; Fellows, 2012).

Besides these, communication also promotes co-operation and industrial peace by promoting cooperation between employer and employees. The base of leadership cannot be possible without effective communication between manager and his/her subordinators (Clampitt\& Downs, 1993; Duncan \& Moriarty,1998). Communication becomes mediator between them in order to maintain people to people relationship. Furthermore, communication plays vital role in motivation and moral, effective control and increase managerial capacity. It increases productivity and reduces cost, increases job satisfaction and creates democratic management (Rahman\&Masoon, 2015).

Additionally, effective communication includes investors and various high skilled employees. Now, the banking organization has intergrated the information technology. The banking sector developing digital platform for its services the transformation results attracts new customer. Ishaq Bhatti et al., (2011) explained banking communication focuses on the customer satisfaction mainly depends on the employees' behavior towards customer. Moreover, employees performance depends on training, technical support, empowerment, rewards, recruitment, performance reviews motivation and selection of employees (Gray \& Laidlaw, 2002).

\section{Banking Communication Theories}

Effective communication system in corporate banking is important for understanding communication from macro to micro levels. Moreover, screening and monitoring employees improve management efficiency through effective communications (Calomiris\&Pornojngkool,2009).The ground theory is based on the corporate banking market linking with corporation, banks, managers and shareholders. Moreover, it also concretizes the relationship between employees, bank and customers. The grounded theory model shows the relationship between managers, shareholders, employees and customers. The model divided into three parts i.e., casual condition, action/interaction and consequences. Likewise, expectation communication system model was prepared to control internal management system in an organization. Expectation communication system approach is used in banking system as it manages communication audit, organization analysis and development, management control system and individual and group development (Martin et.al 2014). Furthermore, commu- 
nication audit is useful in baking sector because it reflects personal behavior, interpersonal relations and group participation. Personal behavior reflects its working attitude towards the organization. It reveals employees' satisfaction level and their expectations (Machin, 1997).

Moreover, the COSO framework strengthens internal control system (Martin et al., 2014). The COSO framework prevents banking communication frauds and errors through effective and efficient operation (Rubino et al., 2014). The COSO framework presents five principles and components which increase the managerial performance through proper analysis of financial statements. The five components reflect risk assessment, control environment, control activities, monitoring activities and information and communications. Moreover, the COBIT framework objective is to provide business requirements, IT process and IT resources (Beuselinck \& Manigrat, 2007; Rubino et al., 2014). Additionally, Berenstein \& Campbell (2002) examined the condition of today's business practices based on the internet and web based users. Using online services, banks transformed traditional clerical works into digital platforms. Online service serves as a bridge between customers and banks through creating networks, technologies and computing system. Additionally, online services digitalized the work to be performed with the help of digital signatures, encryption, digital certificates virtual private networks, security protocols and so on (Deshmukh, 2014).

Similarly, Douglas MC Gregor explained two assumptions of human behavior i.e. Theory $\mathrm{X}$ and Theory $\mathrm{Y}$. Theory $\mathrm{X}$ believes in the traditional methods whereas Theory $\mathrm{Y}$ is based on the behavioral science and modern social science of employees and workers. Those banks that regulate Theory $\mathrm{X}$ concept show authoritarian, repressive, tight control, no development, produce limited and depressed culture. Whereas, banks that accept Theory Y concept are liberal and developmental. They control, achieve and continuously improve the organization through empowering and providing responsibilities to employees.

\section{Empirical Review on Banking Communication}

To understand bankers' experience on banking communication globally, empirical review on banking communications was carried out. Machin (1977) argues keeping systematic records of data and information promotes the systematic recording system of knowledge management in organization. Further Shaikh (2014) found positive relationship between improved quality services and increase efficiency. Vella et al. (2013) in their Europe based study observed that service providers have adopted web-based customer relationship management for marketing. It highlights that bank should provide regular training to the managers about the customer relation management system. Legal and security issues (Shaikh, 2014) introduce advance technology, service and product quality (Abdul et al., 2017); adopt new technology to satisfy their customer through tangibility, reliability, empathy, assurance and responsiveness (Alexiadou et al., 2017), proper management of liquid and credit (Lee \& Isa, 2017).

Addition to this, as Sang et al. (2018) said, trust, communication share value, reciprocity and empathy are the major factors to promote banks and customers relations. South Asia is growing economy where banking system has much to work for better communication and customers' relation. Table 1 shows some empirical studies conducted in South Asian Region. 
Table 1: South Asian Reviews on Banker's Experience on Banking Communication

\begin{tabular}{|c|c|c|c|c|}
\hline Authors & Study & Method & $\begin{array}{l}\text { Major findings / } \\
\text { Results }\end{array}$ & $\begin{array}{l}\text { Conclusions/ } \\
\text { Recommendation }\end{array}$ \\
\hline $\begin{array}{l}\text { Jayasinghe\&Soobaroyen, } \\
\text { (2009), Srilanka }\end{array}$ & $\begin{array}{l}\text { Religious "spirit" } \\
\text { and peoples' } \\
\text { perceptions of } \\
\text { accountability } \\
\text { in Hindu and } \\
\text { Buddhist } \\
\text { religious } \\
\text { organizations }\end{array}$ & $\begin{array}{l}\text { Ethnographic } \\
\text { measure }\end{array}$ & $\begin{array}{l}\text { Religious sprit } \\
\text { connects with social } \\
\text { status, rivalries } \\
\text { and power that } \\
\text { strengthen the } \\
\text { accountability } \\
\text { behavior of people } \\
\text { towards workplace. }\end{array}$ & $\begin{array}{l}\text { Promoting loyalty, } \\
\text { trust and aspiration } \\
\text { towards religions } \\
\text { increase presence } \\
\text { of accountability in } \\
\text { society. } \\
\text {. }\end{array}$ \\
\hline $\begin{array}{l}\text { Ishaq Bhatti et al. (2011), } \\
\text { Pakistan }\end{array}$ & $\begin{array}{l}\text { Employees' } \\
\text { perspective of } \\
\text { organizational } \\
\text { service quality } \\
\text { orientation }\end{array}$ & $\begin{array}{l}\text { Regression } \\
\text { methods }\end{array}$ & $\begin{array}{l}\text { Training and } \\
\text { development } \\
\text { improve service } \\
\text { quality }\end{array}$ & $\begin{array}{l}\text { Develop human } \\
\text { resource capabilities. }\end{array}$ \\
\hline $\begin{array}{l}\text { Murari\& Tater (2014), } \\
\text { Rajasthan }\end{array}$ & $\begin{array}{l}\text { Employee's } \\
\text { attitude towards } \\
\text { adoption of IT- } \\
\text { based banking } \\
\text { services }\end{array}$ & $\begin{array}{l}\text { Convenience } \\
\text { sample } \\
\text { technique }\end{array}$ & $\begin{array}{l}\text { Build customer } \\
\text { satisfaction and } \\
\text { increase operational } \\
\text { efficiency. }\end{array}$ & $\begin{array}{l}\text { Adoption of IT in } \\
\text { organization. }\end{array}$ \\
\hline Kaur (2015), India & $\begin{array}{l}\text { Perception of } \\
\text { bank employees' } \\
\text { towards working } \\
\text { environment of } \\
\text { selected Indian } \\
\text { universal banks }\end{array}$ & $\begin{array}{l}\text { Convenience } \\
\text { sample } \\
\text { technique }\end{array}$ & $\begin{array}{l}\text { Motivation and } \\
\text { Reward are } \\
\text { influencing factor }\end{array}$ & $\begin{array}{l}\text { Avoid conflict among } \\
\text { employees }\end{array}$ \\
\hline $\begin{array}{l}\text { Rahman\&Masoon (2015), } \\
\text { Bangladesh }\end{array}$ & $\begin{array}{l}\text { Effects of } \\
\text { Relationship } \\
\text { Marketing } \\
\text { on Customer } \\
\text { Retention and } \\
\text { Competitive } \\
\text { Advantage }\end{array}$ & $\begin{array}{l}\text { Exploratory } \\
\text { research design }\end{array}$ & $\begin{array}{l}\text { Lack of internal } \\
\text { marketing creates } \\
\text { dissatisfaction } \\
\text { among the } \\
\text { employees. }\end{array}$ & $\begin{array}{l}\text { Proper relationship } \\
\text { between marketing } \\
\text { and customer } \\
\text { retention create } \\
\text { competitive } \\
\text { advantage. }\end{array}$ \\
\hline $\begin{array}{l}\text { Agrawal et al. } \\
\text { (2017), North Indian }\end{array}$ & $\begin{array}{l}\text { Perception } \\
\text { of employees } \\
\text { toward } \\
\text { e-learning } \\
\text { service quality }\end{array}$ & $\begin{array}{l}\text { Exploratory } \\
\text { factor analysis }\end{array}$ & $\begin{array}{l}\text { E-learning system } \\
\text { service is easy to } \\
\text { use, user friendly, } \\
\text { provides high speed } \\
\text { information access, } \\
\text { provide online } \\
\text { assistance and } \\
\text { explanation. }\end{array}$ & $\begin{array}{l}\text { Promoting e-banking } \\
\text { through video content } \\
\text { delivery, employee } \\
\text { interactions, remote } \\
\text { test administration, } \\
\text { up to data materials } \\
\text { and self learning }\end{array}$ \\
\hline
\end{tabular}

From Table 1, it is evidenced that banking communication requires effective communication and human resource management. E-banking is now growing concern today. Further, as Hossian and Leo (2009) argue bank should focus on service quality of bank, customer loyalty, preference and choice in order to create positive customers perceptions. Success of banking relations heavily depends on such behaviors.

\section{Conceptual Framework}

The conceptual framework is generally based on the information related to the literature of 
study that guides to plot the effective framework model. The structural representation of framework shows the relationship with employees and bank. The argumentation directly impacts on the nature of work performance in workplace (Thomos et al., 2009; Alleyne et al., 2009). Both organizational communication and effective communication increase the productivity of employees. Smith \&Mounter (2005) explained that communication improves internal control system, it increases responsibility of CEOs and line managers towards maintaining communication effectively and efficiently (Van Vurren et al., 2006).

Communication role is to interact between manager and employees, it increases sense of team work, increase motivation level, competence, create emotional boundaries, quality performance of employees and gain competitive advantage (Holtzhausen,2002). If the communication fails in organizations, it leads to the dis-functioning of organizational activities. In case of unbalance of communication in employees, supervisors and subordinates, it increases the chances of negative attitudes inside the entire organization. Thus, it becomes difficult task for the management department to manage communication in proper manner. But, once communication is managed, it spreads positive word of mouth inside and outside the organization (Clampitt\& Downs,1993; Desanctis\&Fulk, 1999)).

The conceptual framework highlights overall banking communication. The conceptual framework represents three latent construct variables, namely banking system, employee's behavior and core banking service facilities management. Likewise, banking system works for achieving goals and shapes the strategy for competitive advantage through financial service management, human resource management, corporate influence and organizational regulations (Rus et al., 2015). Additionally, banking communication is interrelated with the employees' behaviors. The behavior of the employees can be measured by communication culture, responsiveness and organizational culture (Yaseen\&Qirem, 2017). Likewise, core banking service facilities management can be driven through e-banking facilities, organizational functioning and communication encounters (Calomiris \& Pornojnangkok, 2009)

\section{Discussion}

The advancement of information and communication technology is influencing working styles of banking sector. The banks and financial institutions are improving technological aspects to sustain in competitive world (Mohammadi, 2015). The latest technology adopted by bank and financial institutions are electronic banking where activities are performed on the basis of electronic channels through mobile phone, internet, telephone etc. (Sharma, 2011). Likewise, the advancement of technology has direct impact on changing the styles of banking styles. The banking industry has been changed into the digitalization and networking technologies to deliver quality service at lower cost with high quality, satisfying customers and stakeholders (Murari \& Tater, 2014). E-banking service is the combination of conventional banking, social computing and internet banking. Moreover, e- banking focuses on profitability and performance of employees (Nardi, 2005).

Moreover, banks are shifted to electronic banking to cut costs maintaining reliable customer services. Now a days, banking industry, being the spirit of financial sector of banking system, has been used by most of the banks all over the world (Mansour et al. 2016). Moreover, financial industry shows direct connection with the economic revolution. Financial in- 
Figure 1: Conceptual Framework

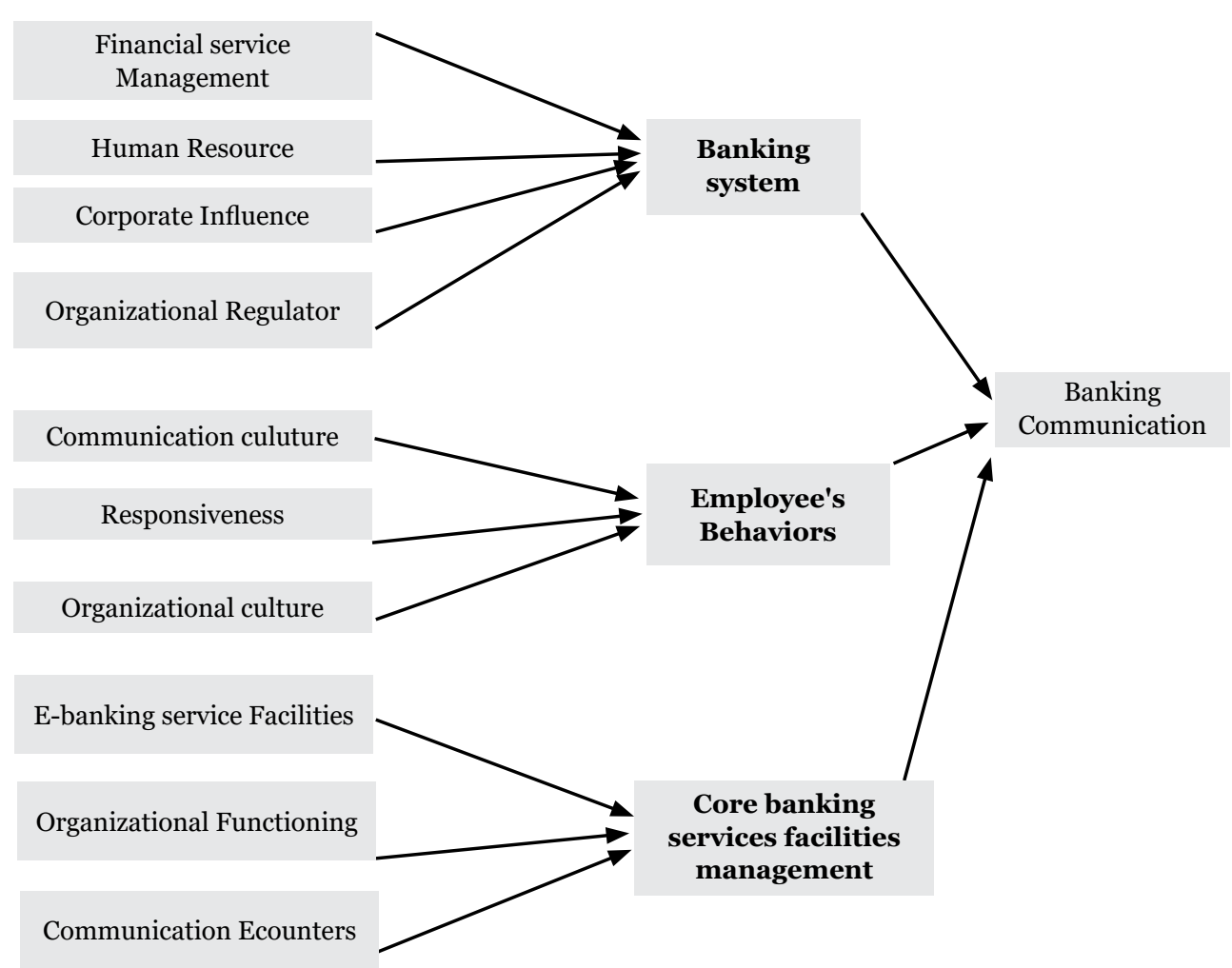

Source: Modified from Yeo \&Youseef (2010)

dustries are promoting technological innovations for the economic development of a nation. Economic evolution is based on monitoring managers, mobilizing savings, managing risks, evaluating projects, and facilitating transactions. Banking management system maintains good relation with employees to understand employee characteristics. Human resource management has become managerial approach that prepares significant progress in effective management of human resources (Pant \& Dangol, 2009).

\section{Conclusion}

The origin of communication started from human interaction. With the passage of time, the communication pattern has changed in the forms of telephone, email and fax into instant messaging/chat, virtual words, social networking sites, wikis, twitter, blogs in the workplace and, over time, it has become very effective and beneficial in transferring information from one place to another place and saving data and information. In modern era, communication channel is transformed into electronic channel promoting e-banking that includes internet banking, mobile banking and e-payment system. Moreover, banking communication is a relationship between communication management and banking system. Proper banking man- 
agement communications create customer satisfaction and bank loyalty. Financial institution like bank are encouraged to promote banking communication management because it fosters economic development as it manages risks, monitors managers, evaluates project, mobilizes saving and facilitates transaction. Likewise, effective communication facilitates cooperation, increases managerial efficiency, promotes cooperation and industry peace, smooth and efficient running of organization, job satisfaction, public relation, increase productivity and reduce cost, democratic management and basis of decision making and planning. From the critical discussion so far, we conclude that managers need to understand importance of communication skills in order to increase effectiveness of internal communication between manager and employees. Thus, proper management of e-banking promotes effective functioning of the organization, smooth running of the organization, proper planning and coordination, exchange of information and maintain human relation. Therefore, every bank and financial institution should focus on the management of communication in bank. The mismanagement of communication leads to increase stress and frustrations in organizations.

\section{Acknowledgement}

Earlier version of this paper has been presented at International Business Conference (IBC, 2019) in Mid-western University; Surkhet, Nepal dated 14th-15th July 2019.

\section{Conflict of Interest}

No conflict of interest is to be declared in this paper.

\section{References}

Abdul-Wahab, A. H., \& Haron, R. (2017). Efficiency of Qatari banking industry: an empirical investigation. International Journal of Bank Marketing, 35(2), 298-318.

Agrawal, V., Agarwal, S., \&Agrawal, A. M. (2017). Perception of employees toward e-learning service quality: exploratory factor analysis. Industrial and Commercial Training, 49(7/8), 350-356.

Ahmad, A. H. (2006). Auditing communication satisfaction among academic staff: An approach to managing academic excellence. The Business Review, 5(1), 330-333.

Akmajian, A., Farmer, A. K., Bickmore, L., Demers, R. A., \&Harnish, R. M. (2017). Linguistics: An introduction to language and communication. MIT press.

Aladwani, A. M. (2001). Online banking: a field study of drivers, development challenges, and expectations. International Journal of Information Management, 21(3), 213-225.

Alexiadou, C., Stylos, N., Andronikidis, A., Bellou, V., \&Vassiliadis, C. A. (2017). Quality in bank service encounters: Assessing the equivalence of customers' and front-line employees' perceptions. International Journal of Quality \& Reliability Management, 34(9), 1431-1450.

Alleyne, C., Kakabadse, A., \&Kakabadse, N. (2007).Using the HR intranet: An exploratory analysis of its impact on managerial satisfaction with the HR function. Personnel Review, 36(2), 295-310.

Altınöz, M. (2009).An overall approach to the communication of organizations in conventional and virtual offices. International Journal of Social Sciences, 4(3), 217-223.

Amato, J. D., Morris, S., \& Shin, H. S. (2002).Communication and monetary policy. Oxford Review of Economic Policy, 18(4), 495-503.

Aral, S., Dellarocas, C., \&Godes, D. (2013). Introduction to the special issue-social media and business transformation: a framework for research. Information Systems Research, 24(1), 3-13. 
Arnold, E., \& Silva, N. (2011). Perceptions of organizational communication processes in quality management. Revista de psicologia, 29(1), 153-174.

Austin, E. W., \&Pinkleton, B. E. (2015). Strategic public relations management: Planning and managing effective communication campaigns. Routledge.

Bennett, R., \& Kottasz, R. (2012). Public attitudes towards the UK banking industry following the global financial crisis. International Journal of Bank Marketing, 3o(2), 128-147.

Berenstein, G. L., \& Campbell, C. E. (2002). Electronic contracting: The current state of the law and best practices. Intellectual Property \& Technology Law Journal, 14(9), 1-1.

Beuselinck, C., \&Manigart, S. (2007). Financial reporting quality in private equity backed companies: The impact of ownership concentration. Small Business Economics, 29(3), 261-274

BK, A., Mahato, A., Thapa, S., Rai, A. \&Devkota, N. (2019).Achieving Nepal's sustainable development goals 2016 - 2030 by effective corporate governance. Quest Journal of Management and Social Sciences: Corporate Governance Edition, 1(1), 50-72.

Borca, C., \&Baesu, V. (2014).A possible managerial approach for internal organizational communication characterization. Procedia-Social and Behavioral Sciences, 124, 496-503.

Calomiris, C. W., \&Pornrojnangkool, T. (2009).Relationship banking and the pricing of financial services. Journal of Financial Services Research, 35(3), 189-224.

Chen, N. (2008). Internal/Employee Communication and Organizational Effectiveness: a study of Chinese corporations in transition. Journal of Contemporary China, 17(54), 167-189.

Clampitt, P. G., \& Downs, C. W. (1993). Employee perceptions of the relationship between communication and productivity: A field study. The Journal of Business Communication (1973), 30(1), 5-28.

Cudjoe, A. G., Anim, P. A., \&Nyanyofio, J. G. N. T. (2015). Determinants of mobile banking adoption in the Ghanaian banking industry: a case of access bank Ghana limited. Journal of Computer and Communications, 3(02), 1.

DeSanctis, G., \&Fulk, J. (1999). Shaping organization form: Communication, connection, and community.Sage.

Deshmukh, A. (2004). A conceptual framework for online internal controls.Journal of Information Technology Management, 15(3/4), 23-32.

Duncan, T., \& Moriarty, S. E. (1998).A communication-based marketing model for managing relationships. Journal of marketing, 62(2), 1-13.

Fellows, N. V. (2012). Organizational Communication at XYZ Company (Doctoral dissertation). University of Wisconsin-Stout, Madinson.

Femi, A. F. (2014). The impact of communication on workers' performance in selected organisations in Lagos State, Nigeria. IOSR Journal of humanities and Social Science, 19(8), 75-82.

Gray, J., \& Laidlaw, H. (2002). Part-time employment and communication satisfaction in an Australian retail organisation. Employee Relations, 24(2), 211-228.

Hargie, O., Tourish, D., \& Wilson, N. (2002). Communication audits and the effects of increased information: A follow-up study. The Journal of Business Communication (1973), 39(4), 414-436.

Holtzhausen, D. (2002). The effects of a divisionalised and decentralized organisational structure on a formal internal communication function in a South African organisation. Journal of communication management, 6(4), 323-339.

Hossain, M., \& Leo, S. (2009). Customer perception on service quality in retail banking in Middle East: the case of Qatar. International Journal of Islamic and Middle Eastern Finance and Management, 2(4), 338-350. 
IshaqBhatti, M., Zafarullah, M., Awan, H. M., \&Bukhari, K. S. (2011). Employees' perspective of organizational service quality orientation: Evidence from Islamic banking industry. International Journal of Islamic and Middle Eastern Finance and Management, 4(4), 280-294.

Jayasinghe, K., \&Soobaroyen, T. (2009). Religious "spirit" and peoples' perceptions of accountability in Hindu and Buddhist religious organizations. Accounting, Auditing \& Accountability Journal, 22(7), 997-1028.

Kaur, G. (2015). Perception of bank employees' towards working environment of selected Indian universal banks. International Journal of Bank Marketing, 33(1), 58-77.

Keyton, J., Caputo, J. M., Ford, E. A., Fu, R., Leibowitz, S. A., Liu, T., \& Wu, C. (2013). Investigating verbal workplace communication behaviors. The Journal of Business Communication (1973), $50(2), 152-169$.

Kurland, N. B., \& Bailey, D. E. (2000). Telework: The advantages and challenges of working here, there, anywhere, and anytime. IEEE Engineering Management Review, 28(2), 49-60.

Lee, S. P., \& Isa, M. (2017). Determinants of bank margins in a dual banking system. Managerial Finance, 43(6), 630-645.

Machin, J. (1977). Using the expectations approach to improve managerial communication and organizational effectiveness. Management Decision, 15(2), 259-277

Mansour, I. H. F., Eljelly, A. M., \& Abdullah, A. M. (2016). Consumers' attitude towards e-banking services in Islamic banks: the case of Sudan. Review of International Business and Strategy, 26(2), 244-260.

Martin, K., Sanders, E., \&Scalan, G. (2014). The potential impact of COSO internal control integrated framework revision on internal audit structured SOX work programs. Research in Accounting Regulation, 26(1), 110-117.

Mohammadi, H. (2015). A study of mobile banking loyalty in Iran. Computers in Human Behavior, $44,35-47$.

Murari, K., \& Tater, B. (2014). Employee's attitude towards adoption of IT-based banking services: A case of Indian private sector banks. Competitiveness Review, 24(2), 107-118.

Nardi, B. A. (2005). Beyond bandwidth: Dimensions of connection in interpersonal communication. Computer Supported Cooperative Work (CSCW), 14(2), 91-130.

OlyNdubisi, N. (2007). Relationship quality antecedents: the Malaysian retail banking perspective. International Journal of Quality \& Reliability Management, 24(8), 829-845.

Pant, P. R., \& Dangol, D. (2009). Kathmandu valley profile. Briefing Paper, Governance and Infrastructure Development Challenges in Kathmandu Valley.

Power, M., \&Rienstra, B. (1999). Internal communication in new corporate conglomerates: Developing a corporate communication model for loosely coupled businesses in local government. International Journal of Public Sector Management, 12(6), 501-515.

Rahman, S. A. U., \&Masoom, M. R. (2015). Effects of relationship marketing on customer retention and competitive advantage: A case study on Grameen Phone Ltd. Asian Business Review, 1(2), 97-102.

Rai, R., Kharel, S., Devkota, N., \& Paudel, U. R. (2019).Customers perception on green banking practices: A desk. The Journal of Economic Concerns, 1O(1), 82-95.

Rubino, M., \&Vitolla, F. (2014). Internal control over financial reporting: opportunities using the COBIT framework. Managerial Auditing Journal, 29(8), 736-771.

Rus, S., Mocan, M., Ardelean, B. O., Ivascu, L., \& Cioca, L. I. (2016). Conceptualization and examination of success factors in the banking system. Procedia Economics and Finance, 39, 679-684. 
Sadia, A., Salleh, B. M., Kadir, Z. A., \& Sanif, S. (2016). The relationship between organizational communication and employees productivity with new dimensions of effective communication flow. Journal of Business and Social Review in Emerging Economies, 2(2), 93-100.

Sang, H., Ngamau, N. W., \&Ragama, P. (2018).Effects of strategic alignment on the performance of non-governmental organizations in Nakuru town, Kenya. International Journal of Business and Processes, 4(2), 21-21.

Scornavacca, E., \& Hoehle, H. (2007). Mobile banking in Germany: A strategic perspective. International Journal of Electronic Finance, 1(3), 304-320.

Shaikh, M. A. (2014). Ethiopian banker's perception of electronic banking in Ethiopia-A case of Adama City. International Journal of Scientific and Research Publication, 4(9).

Sharma, H. (2011). Bankers' perspectives on e-banking. Global journal of Research in Management, 1(1), 71.

Smith, L., \&Mounter, P. (2008). Effective internal communication. Kogan Page Publishers.

Smythe, J. (1996). The changing role of internal communication in tomorrow's company. Managing Service Quality: An International Journal, 6(2), 41-44.

Svensson, G. (2004). Interactive service quality in service encounters: empirical illustration and models. Managing Service Quality: An International Journal, 14(4), 278-287.

Thomas, G. F., Zolin, R., \& Hartman, J. L. (2009).The central role of communication in developing trust and its effect on employee involvement. The Journal of Business Communication (1973), 46(3), 287-310.

Thomson, K., \&Hecker, L. (2001). Value-adding communication: Innovation in employee communication and internal marketing. Journal of Communication Management, 5(1), 48-58.

Thussu, D. K. (2018). International communication: Continuity and change. Bloomsbury Publishing

Turner, T., Qvarfordt, P., Biehl, J. T., Golovchinsky, G., \& Back, M. (2010, April).Exploring the workplace communication ecology.In Proceedings of the SIGCHI conference on human factors in computing systems (pp. 841-850).ACM.

Van Eemeren, F. H., \&Grootendorst, R. (2016). Argumentation, communication, and fallacies: A pragma-dialectical perspective. Routledge.

Van Vuuren, M., de Jong, M. D., \&Seydel, E. R. (2007).Direct and indirect effects of supervisor communication on organizational commitment. Corporate Communications: An International Journal, 12(2), 116-128.

Vella, J., Caruana, A., \& Pitt, L. (2013). Organizational commitment and users' perception of ease of use: A study among bank managers. Journal of Management Development, 32(4), 351-362.

Yaseen, S. G., \& El Qirem, I. A. (2018). Intention to use e-banking services in the Jordanian commercial banks. International Journal of Bank Marketing, 36(3), 557-571.

Yeo, R. K., \& Youssef, M. A. (2010). Communicating corporate image into existence: the case of the Saudi banking industry. Corporate Communications: An International Journal, 15(3), 263-280 